\title{
Current Status of Liquid-cell Transmission Electron Microscopy
}

\author{
Jaeyoung Hong and Dong Won Chun ${ }^{\dagger}$
}

Advanced Analysis Center, Korea Institute of Science and Technology

\section{액상 투과전자현미경 분석기법 소개 및 최신 연구동향}

\author{
홍재영, 천동원 ${ }^{\dagger}$ \\ 한국과학기술연구원 특성분석센터
}

(Received December 17, 2019 ; Accepted December 20, 2019)

\begin{abstract}
s
Even though, nanoscale materials of various shapes and compositions have been synthesized in the liquid, their underlying growth and transformation mechanisms are not well understood due to a lack of analytical methods. The advent of liquid cell for transmission electron microscope (TEM) enables the direct imaging of chemical reactions that occur in liquids with nanometer resolution of the electron microscope (EM). Here, the technical development of liquid cell TEM equipment and their applications to the study of nanomaterials analysis in liquid are discussed. Also new findings discovered through liquid cell TEM studies such as nucleation \& growth, coalescence process and transformation are discussed.
\end{abstract}

\section{1. 서론}

우리는 높은 분해능(Spatial Resolution)을 갖는 전자현 미경(Electron Microscope)을 통해 기존의 광학 현미경 (Optical Microscope)을 통해 볼 수 없었던 소재의 결정구 조(Crystal Structure), 원자배열(Atomic Arrangement) 및 화학구조(Chemical Structure) 등을 이미징 할 수 있 다. 일반적으로 전자현미경을 통한 관찰 연구는 고진공상 태의 고체시료(Solid samples) 분석에 국한되고 있는 실
정이다. 하지만 소재의 합성 및 제작된 소재의 응용은 기 체/액체 환경 등 다양한 반응환경에서 이루어 진다. 따라 서 소재의 성장과정 및 반응환경 하 작동과정 등에 대한 이 해를 위해서는 반응환경 하 소재를 분석하는것이 반드시 필요함에도 불구하고 액체 환경 하 전자현미경 분석시 발 생하는 분해능 저하 및 실험중 발생가능한 액체의 누설로 인한 장비 고장문제 등으로 인해 관련 연구가 활발히 진행 되지 못하고 있는 상황이였다.

투과전자현미경 (Transmission Electron Microscope: 


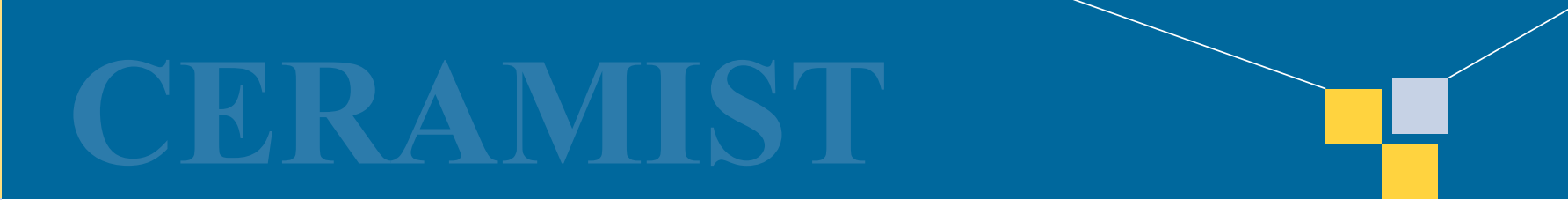

특 집 홍재영, 천동원

$\mathrm{TEM}$ )의 이미징 원리는 전자빔이 샘플을 투과하면서 발 생하는 탄성산란 (Elastic Scattering)과 투과빔과의 상 차이 (Phase difference)를 이미지화 시키는 것이다. 따 라서 우리가 측정하고자 하는 시편 이외에서 발생하는 전 자빔과의 탄성산란 및 비탄성산란 (Inelastic Scattering) 은 궁즉적으로 시편이 잘 보이지 않게 하는 노이즈 역할 을 하게 된다. 액상셀(Liquid Cell)의 경우 고진공 투과전 자현미경 내부환경에서 액체의 증발을 막기 위한 보호층 (Protection layer)이 필요한데, 이 보호층의 두께가 두꺼 울 수록 투과전자현미경의 분해능이 현격히 저하한다. 또 한 액체 자체의 두께가 존재하므로 액체의 두께 또한 얇 아야 하는 기술적 문제가 존재한다.

하지만, 최근의 눈부신 분석장비 제작기술의 발전은 액 체 환경속 시료의 분석이 가능하게 되었다. 특히 전자빔과 의 탄성/비탄성 산란을 저하시키는 소재의 사용 및 액체 보호층의 두께를 얇게 하여 분해능을 현격히 향상시켰다. 이것은 액체속에서 일어나는 중요한 화학 / 물리 / 생물학 적 반응을 정밀하게 관찰할 수 있음을 의미한다. 특히 고 분해능 액상 (Liquid Cell) 투과전자현미경 (Transmission Electron Microscope: TEM)을 이용한 연구를 통해, 액체 안에서 일어나는 소재의 성장 및 반응과정을 원자수준레
벨의 실시간 관찰이 가능하게 되었다.

본 보고에서는 액상 투과전자현미경 셀의 발전 현황에 대해 다루었다. 액상 투과전자현미경은 바이오공학 / 이 차전지 / 나노입자 촉매 등 다양한 분야에 응용되어 연구 가 진행되고 있다. 이중에서 우수한 연구 결과들이 보고 되고 있는 액상 투과전자현미경을 이용한 나노입자 분석 연구 현황 및 예를 본 보고에서 기술하였다.

\section{2. 본론}

\section{2-1. 액상 투과전자현미경 분석장비}

투과전자현미경 내부는 $10^{-8}$ torr 정도의 고진공으로 유지되기에 액체를 포함한 시편일 경우 모든 액체가 증발 이 된다. 이러한 당면한 문제점, 즉 현미경 내에서 액체 를 관찰하기 위하여 고진공 분위기에서 액체를 보호할 수 있는 액상 셀을 개발하기 위한 연구들이 집중적으로 진행 되었고, 이를 통해 상용화된 제품 개발이 완성되었다. 현 재는 상용제품을 통해 누구든지 전자현미경 내에서 액체 안 시편을 관찰할 수 있게 되었다. 상용화 액상셀의 경우, 일반적으로 얇은 $\mathrm{Si}_{3} \mathrm{~N}_{4}$ 박막을 이용하여 만들어진 두 칩 사이에 액체를 넣고 조립하여 액체가 있는 공간과 진공

(a)
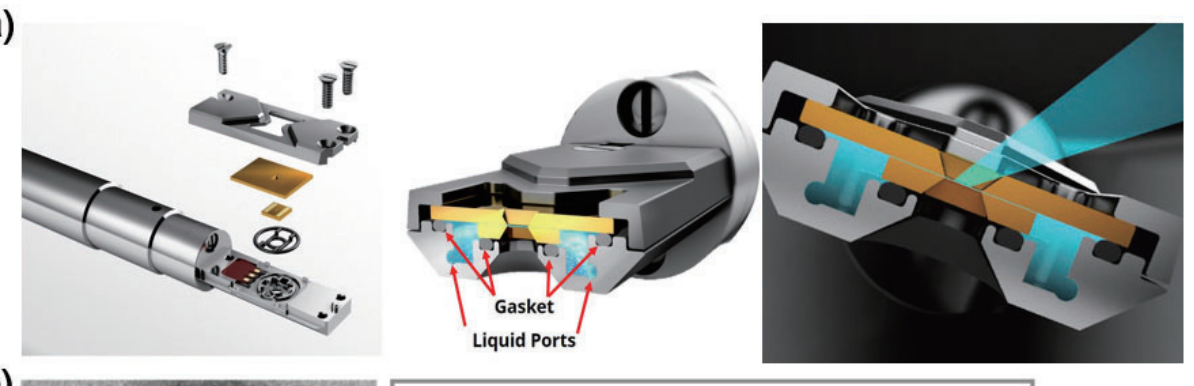

(b)
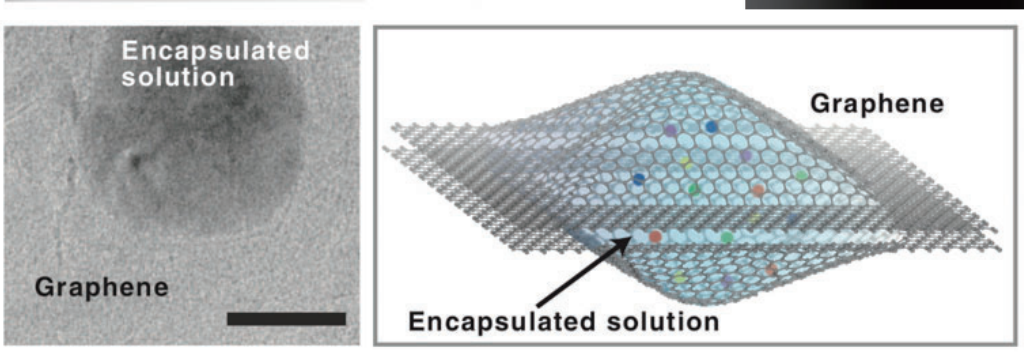

그림 1. (a) Schematic diagram of commercial $\mathrm{Si}_{3} \mathrm{~N}_{4}$ window liquid cell (Protochips Poseidon) $)^{2}$ (b) TEM image and schematic diagram of graphene liquid cell ${ }^{3}$ 
분위기의 공간을 완전히 분리시키는 형태로 제작이 된다. 두 칩이 완전히 달라붙으면 액체가 들어있을 공간이 없기 때문에 액체가 있을 공간을 확보하는 spacer가 한 쪽 칩 에 붙어있어서, 현미경 내 고진공 분위기에서 특정 두께 의 액체를 유지하며 관찰할 수 있게 한다. ${ }^{1}$

투과전자현미경은 현미경의 전자총 부분에서 나온 전 자가 시편을 투과하여 카메라에 도달하면 카메라에서 전 기적으로 신호를 처리하여 사용자가 인식할 수 있는 이미 지를 만들어주는 방식으로 작동한다. 전자가 시편을 투과 하는게 가장 기본적인 관측 조건이기에, 일반적으로 시편 두께가 수백 나노미터 이하여야 하고, 얇으면 얇을수록 높은 해상도의 이미지를 얻을 수 있고 결정성 등의 정보 를 얻을 수 있는 가능성이 커진다.

투과전자현미경 분석이 가능하도록 $\mathrm{Si}_{3} \mathrm{~N}_{4}$ 칩의 중앙 부 분은 수십 나노미터 두께의 얇은 막으로 되서 전자가 쉽 게 투과할 수 있도록 되어 있는데, 그 부분을 윈도우라고 부른다. 현미경의 전자총에서 나온 전자가 위쪽 윈도우를 투과해서 실제 관찰하고자 하는 시편이 들어있는 액체를 투과한 뒤, 마지막으로 아래쪽 윈도우를 투과한 다음에 카메라에 도달하게 된다. 시편을 투과하는 전자가 시편 외에 다른 물질들을 많이 통과할 수록 사용자가 얻는 영 상에 시편의 신호가 아닌 다른 신호들이 많이 들어오게 되어 이미지의 질이 나빠진다. 그래서 윈도우가 얇으면 얇을수록 더 높은 해상도의 이미지를 얻을 수 있지만, 동 시에 안정성이 떨어져서 더 쉽게 깨질 수 있기 때문에 상 용 제품들은 이 둘 사이에서 최적화된 두께로 판매된다. 제조사마다 조금씩 다르지만 보통 50 나노미터 두께의 윈도우가 많이 판매가 되고 있다. 다만 50 나노미터 두께 의 윈도우 제품을 사용할 경우, 액체 영역을 제외하고도 100 나노미터 두께에 해당하는 이물질 신호가 영상에 들 어가게 때문에 액체 내부의 수 나노미터 크기의 입자들은 거의 보이지 않게 된다. 이런 한계 때문에 일부 연구팀은 직접 윈도우 두께가 20 나노미터 이하인 셀을 만들어서 높은 해상도의 이미지 측정 결과를 보고하기도 하였다.

윈도우의 두께로 인한 해상도 저하를 최소화하기 위하 여 개발된 것이 그래핀 액체 셀(Graphene Liquid Cell) 이다. 그래핀의 경우 원자번호가 낮고 그 두께가 매우 얇
기 때문에 전자와의 탄성/비탄성 산란이 현격히 감소한 다. 또한 전기전도도가 좋고 신축성이 좋은 그래핀의 특 성은 전자현미경 내부에서 액체를 가두는데 유리하다. 두 그래핀 사이에 갇힌 액체 주머니는 고진공 분위기에서도 찢어지지 않고 유지된다. 몇 겹의 그래핀을 사용하냐에 따라 달라지긴 하지만, 단일 레이어의 그래핀을 사용할경 우 두께가 1 나노미터가 되지 않는다. 그래핀 셀의 경우 에는 그래핀이 곧 윈도우가 되기 때문에, 상용화된 $\mathrm{Si}_{3} \mathrm{~N}_{4}$ 제품과 달리 윈도우에 의한 해상도 저하가 거의 없어서 고해상도 영상 획득이 가능해진다. 수 나노미터 입자의 결정면까지 보이기에, 고해상도 이미지에서만 얻을 수 있 는 결정정보가 필요한 연구에 용이하다. ${ }^{3}$

다만 그래핀은 투과전자현미경에서 사용되는 전자의 속도에 따라 손상을 입을 수 있다는 문제가 있다. 현미경 의 가속전압이 현미경 내 전자의 속도를 결정짓는데 가속 전압이 높을수록 높은 해상도의 이미지를 얻을 수 있고, 일반적인 금속 시편이나 금속 산화물 시편 관측에는 200 300 kV의 가속전압이 사용된다. 하지만 그래핀의 경우 $80 \mathrm{kV}$ 정도의 가속전압에서 손상을 입는 것으로 알 려져 있기에, 안정적인 관측을 위해서는 $80 \mathrm{kV}$ 이하의 가 속전압을 사용하여야 한다. 해상도 저하를 막기 위해 그 래핀셀을 도입한 것인데 오랜 시간의 관측을 위해서는 해 상도 저하가 수반되는 낮은 가속전압을 사용해야 한다는 것이 조금 아이러니하다. 반대로 $\mathrm{Si}_{3} \mathrm{~N}_{4}$ 는 높은 가속전압 에서 아무 영향을 받지 않기 때문에 좀더 손쉽게 사용가 능하다. 그리고 그래핀셀은 $\mathrm{Si}_{3} \mathrm{~N}_{4}$ 셀과 달리 액체 두께 조 정이 용이하지 않다. Spacer를 통해 원하는 액체 두께를 얻을 수 있는 $\mathrm{Si}_{3} \mathrm{~N}_{4}$ 셀과 달리, 그래핀셀에서 만들어지는 액체 포켓의 두께는 임의로 결정되고, 그 두께를 알아내 기도 어렵다.

즉 그래핀 셀은 높은 분해능의 투과전자현미경 이미지 획득의 장점이 있다. 또한 고가의 액상 셀 구매가 필요 없 이 수작업을 통해 제작 할 수 있기 때문에, 누구든지 상대 적으로 손쉽게 사용이 가능한 장점이 있다. 반면에 $\mathrm{Si}_{3} \mathrm{~N}_{4}$ 기반의 상용화 액상셀의 경우, 일정한 액체 두께에 따른 안정적인 실험관경 구현이 가능한 장점이 있는 반면에, 고분해능 이미지 획득이 어렵고, 고가의 장비를 구매해야 
하는 문제점이 있다. 현재 액상 셀 제작업체에서는 $\mathrm{Si}_{3} \mathrm{~N}_{4}$ 이용하여 고분해능 이미지를 얻기 위한 장비 개발에 매진 하고 있다.

\section{2-2. 나노입자 성장 실시간 관찰연구}

액상 투과전자현미경 분석기법을 통한 나노입자의 생 성 및 성장 거동에 대한 연구가 집중적으로 진행되고 있 다. 전구체 용액을 액상 용기에 넣고 투과전자현미경에서 전자빔을 조사해서 그 안에서 생기는 나노입자를 관찰하 는 연구가 활발히 진행되었는데, 독특한 점은 이런 실험 들이 현미경에서 나오는 전자와 전구체 용액 사이의 화학 반응을 이용한 것이란 것이다. 원래 관측장비들은 관찰 과정 중에 시편에 어떠한 변화도 일으키면 안된다. 하지 만 액상 투과전자현미경은 액체와 전자빔 사이의 반응을 이용하여 나노입자의 생성을 유도하는 연구가 많이 진행 되어 왔다.

투과전자현미경 전자총(Electron Gun) 발생하는 높은 에너지의 전자빔들은 전자기 렌즈(Electromagnetic Lens)를 통화하면서 집속되어 액체에 조사된다. 따라서 단위면적당 높은 에너지의 전자빔이 액체에 조사되게 되 고, 핵 주위를 돌던 전자들과 비탄성 충돌을 일으키게 된 다. 이로 인해 오비탈 내부의 전자들이 외부로 빠져나가 게 되어 수많은 수화전자 (Hydrated Electron)들이 발생
하게 된다. 이와 더불어 환원력을 가진 수소 래디칼이나 산화력을 가진 수산화 래디칼 등 많은 화학물질이 생성되 어지는데 이러한 전자빔과 액체와의 반응과정을 레디올 리시스(Radiolysis)라 한다 (그림2). 수화전자나 수소 라 디칼 등등. 금속 전구체 수용액에 전자빔을 조사하면, 전 구체 용액의 금속 양이온과, 물과 전자빔의 반응에서 생 겨난 환원성을 띄는 물질들이 반응하여 금속 양이온이 환 원되어 Zerovalent 금속 원자가 되고, 이 환원된 금속 원 자들이 모여서 나노입자가 형성된다. 일반적인 현미경 분 석에서는 전자와 시편이 화학적인 반응을 일으키지 않아 야 시편을 정확히 분석할 수 있지만, 나노입자의 합성과 정을 연구하기 위한 투과전자현미경 액상 실험에서는 높 은 에너지의 전자빔이 관찰의 수단이자 합성 반응의 환원 제로서 사용하여, 나노입자를 생성시키면서 동시에 관찰 을 하는 방식으로 진행이 된다.

계산을 통해서 어떤 화학물질이 얼만큼 생기는지를 추 정한 연구에서는 전자빔이 물 내에 어떤 변화를 가져오는 지에 대해 밝혀놓았다. 전자빔 조사에 따라 산성도도 변 하고 수소와 산소 기체가 생기는 것과 전자빔의 조사량에 따라서 환원제와 산화제 비율이 달라져서 조사량이 높을 때는 전체적으로 용액이 환원 분위기가 되지만, 조사량이 낮을 때는 용액이 산화분위기가 되어 형성된 나노입자가 녹아버리는 현상이 관찰되기도 한다. ${ }^{4}$
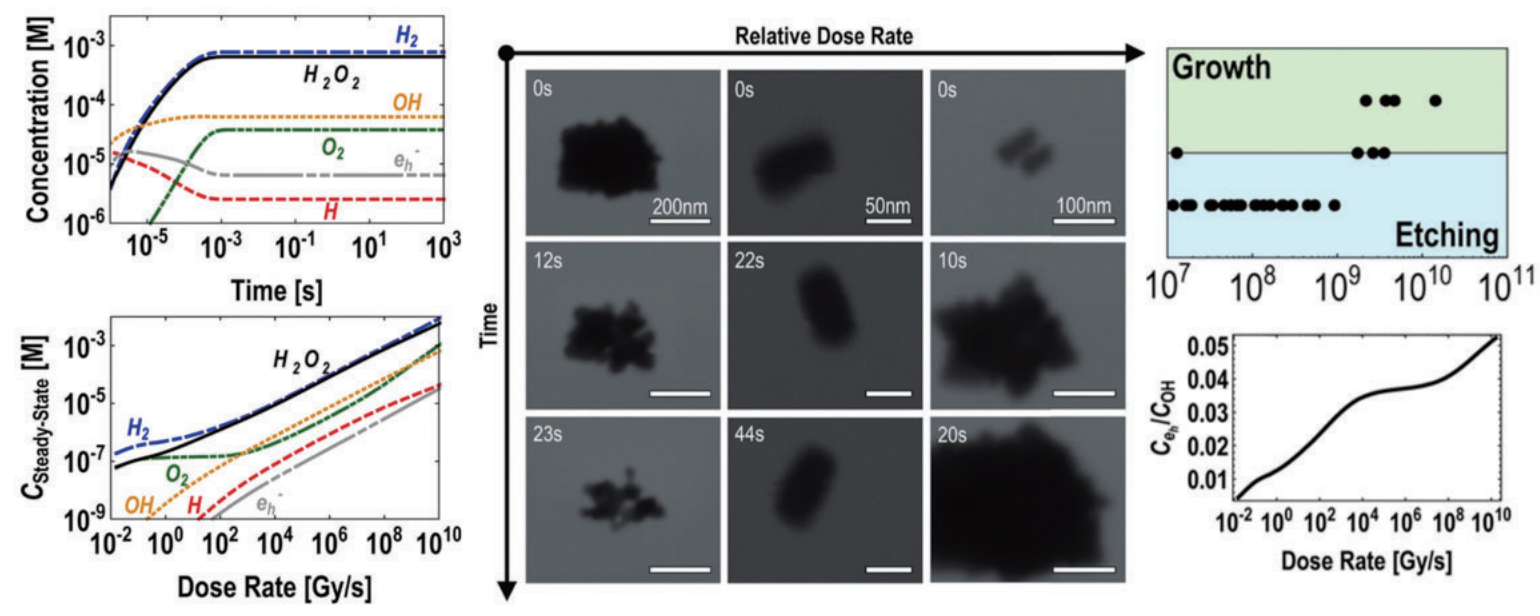

그림2. Concentration of radiolysis products of water depending on time and dose rate. Change in nanoparticles depending on dose rate ${ }^{4}$ 


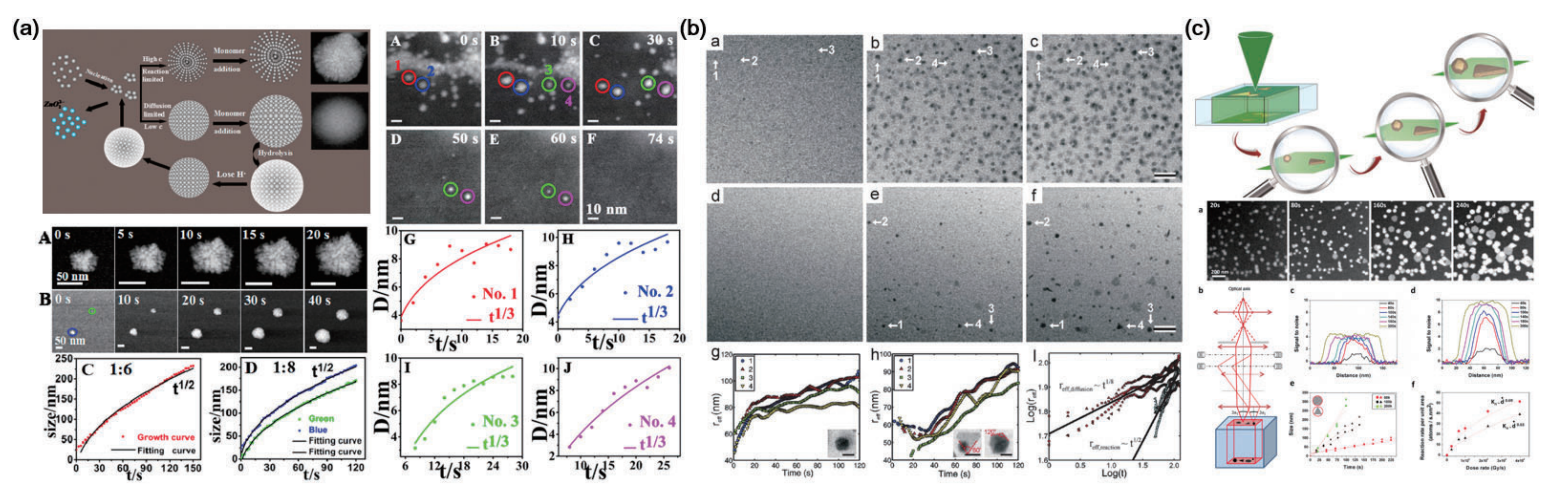

그림 3. (a) Growth mechanism of $\mathrm{ZnO}$ nanoparticles depending on concentration of precursor solution ${ }^{5}$ (b) Growth mechanism of silver nanoparticles depending on dose rate ${ }^{6}$ (c) Evolution of gold nanoplate depending on growth rate ${ }^{7}$

기존에 나노입자 생성과정 ex-situ 연구는 입자 합성 과 정 중간중간에 반응 용액의 일부를 꺼내어 현미경으로 분 석하거나, 현미경이 아닌 다른 분석장비들을 통해 반응 용 액을 실시간으로 분석하여 간접적으로 입자의 성장 과정을 알아내는 방식으로 진행되어 왔다. 하지만 액상셀을 이용 한 in-situ 투과전자현미경 연구를 통해 직접적으로 입자 의 성장 과정을 볼 수 있게 되면서, 기존에는 이론적으로만 이해했거나, 불연속적으로 관찰해서 유추했던 입자 성장 메커니즘을 파악하는 연구가 활발하게 진행되었다.

주로 Lifshitz-Slyozov-Wagner (LSW) model을 기 반으로 한 귀금속 나노입자가 Reaction Limited Growth 와 Diffusion Limited Growth 중 어떤 메커니즘을 따라 서 성장하는지 연구가 되었다. 이 모델은 시간에 따른 나 노입자의 반지름을 측정하여, 시간의 몇 제곱에 비례하여 성장하는지를 가지고 어떤 메커니즘인지 판단하는 모델 이다. 동일한 조사량의 전자빔을 서로 다른 농도의 용액 에 조사할 때, 농도가 높을 때는 금속 이온의 확산 반응이 환원 반응보다 빠르게 일어나게 되어 금속 이온의 환원 반응이 reaction determining step이 되어 전체적으로 reaction limited growth 메커니즘으로 성장하고, 농도 가 낮을 때는 금속 이온의 환원 반응이 빠르게 일어나서 diffusion limited growth메커니즘을 따르게 된다. ${ }^{5}$ 반 대로 동일한 농도의 용액에 전자빔을 조사할 때, 조사량 이 높을 경우에는 확산 반응이 상대적으로 느려서 diffusion limited growth 메커니즘으로 성장하고, 조사
량이 낮은 경우는 환원 반응이 상대적으로 느려서 reaction limited growth 메커니즘으로 성장하는 것을 확인한 연구도 있었다. ${ }^{6}$ 조사량에 따라 입자 성장 속도가 결정되는 것을 확인하여, 조사량을 조절하여 나노입자나 나노플레이트를 만드는 연구도 진행되었다. ${ }^{7}$ (그림3)

현재까지의 액상 투과전자현미경 연구 중 가장 많은 사 람들의 관심을 끈 것은 나노입자의 성장 방식에 대한 기 존 생각을 깨트린 연구였다. 기존 나노입자 성장 이론에 따르면 나노입자는 monomer attachment라 불리는 방 식으로 성장하는데, 이는 nucleation이 일어난 후에 주 변의 monomer들이 핵에 달라붙어서 나노입자가 점점 커지는 메커니즘을 말한다. 여러 개의 입자가 성장하면서 Ostwald ripening이 일어나 큰 입자는 더 커지고, 작은 입자는 더 작아지는 등 액상 합성 과정에서 나노입자의 크기 분포가 어떻게 달라지는지, 어느 순간에 nucleation 이 일어나는지 등에 대해서 많은 연구들이 행해졌었고 이 를 뒷받침하는 이론들이 존재한다. ${ }^{8}$ 하지만 액상 투과전 자현미경 연구를 통해 백금 나노입자의 성장에서 nucleation 후에 입자가 monomer attachment 방식으 로만 성장하는 것이 아니라, 어느 정도 성장한 입자와 다 른 입자가 합쳐지면서 하나의 입자로 자라는 방식으로 성 장하는 것을 밝혀내었는데 이를 coalescence 방식이라고 한다. ${ }^{9}$ 기존의 나노입자 생성 이론에서는 고려되지 않았 던 메커니즘을 처음으로 밝혀내며 실시간 성장 과정 연구 의 위력을 세상에 알린 대표적인 사례이다. (그림4) 

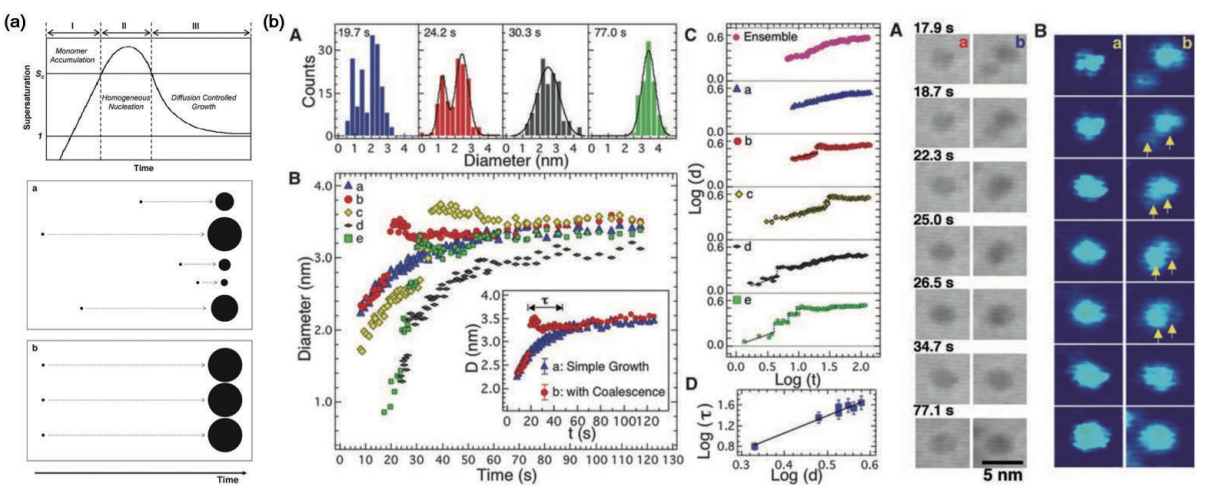

그림 4. (a) Classical nucleation theory of nanoparticles ${ }^{8}$ (b) In-situ observation of platinum nanoparticles and single particle growth trajectories $^{9}$

Coalescence를 통해 입자가 성장하는 것이 확인된 후, 서로 다른 두 입자가 어떤 방식으로 달라붙는지에 대한 연구가 진행되었고 기존에 사용되던 액상 셀에서는 정확 한 coalescence 거동을 심도있게 분석할 수 있는 해상도 가 확보되지 않았기에 고해상도 영상 획득을 위해 새로운 방법들이 시도 되었다. 앞서 말했던 그래핀을 이용한 그 래핀셀이나 $\mathrm{Si}_{3} \mathrm{~N}_{4}$ 윈도우 두께를 아주 얇게 만든 시스템 이 제작되었고, 이를 통해 입자의 결정면이 보이는 영상 을 가지고 연구가 진행되었다. 고배율 영상을 통해서도 입자가 monomer attachment와 coalescence 두 방식 으로 성장하는 것이 확인되었고, 특히 coalescence가 일 어날 때 달라붙어서 하나가 된 나노입자가 원자들의 재배 열이 일어나 단결정이나 twin이 있는 결정이 되는 것이
밝혀졌다. ${ }^{2}$ 다른 두 입자가 합쳐지면서 두 입자 사이에 neck 영역이 먼저 생기고, 상대적으로 폭이 좁은 neck 영역으로 다른 위치에 있던 원자들이 확산을 하여 결국 하나의 굴곡 없는 나노입자로 변하는 과정을 정량적으로 보여주는 연구결과도 발표되었다. ${ }^{10}$ (그림5)

액상에서도 고해상도 관찰이 가능해지면서 나노입자 의 결정면들이 각각 어떤 속도로 자라는지도 연구가 되었 다. 생성 초기에는 구형에 가까운 느낌으로 생겼던 나노 입자가 시간에 지남에 따라 열역학적으로 안정한 형태를 띄게 되면서 에너지적으로 안정한 결정면을 노출시키는 방향으로 성장한다는 결과가 발표되었다. ${ }^{11}$ 액체 내에서 입자가 자유롭게 움직이고 회전하는 성질을 이용하여 추 가적인 기울임 없이 나노입자 tomography를 하는 연구

(a)
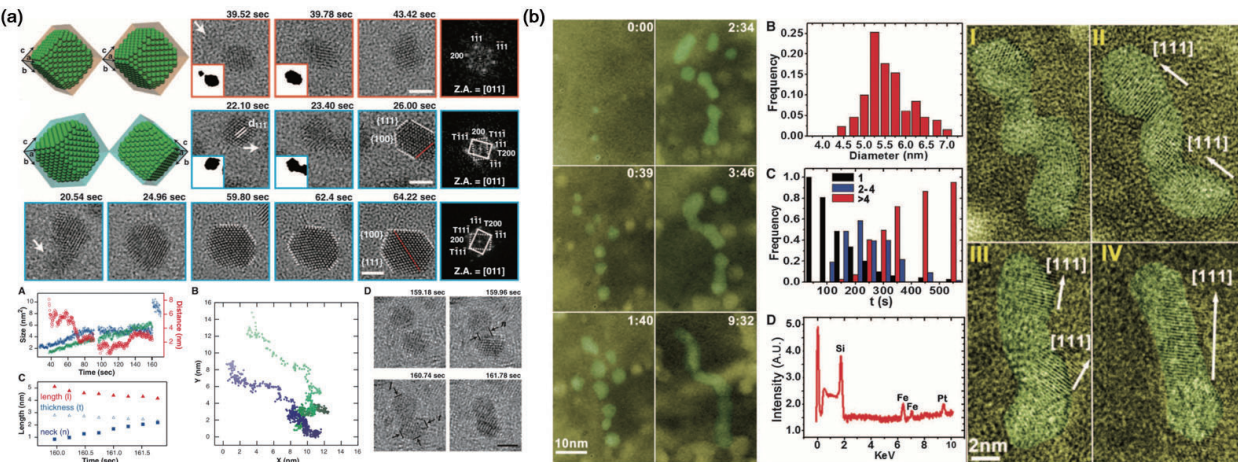

그림5. (a) High resolution image series of coalescing platinum nanoparticles and change in dimension and location of particles during coalescence $^{2}$ (b) Particles coalescence resulting in nanorod and fringe alignment within nanorod after coalescence ${ }^{10}$ 

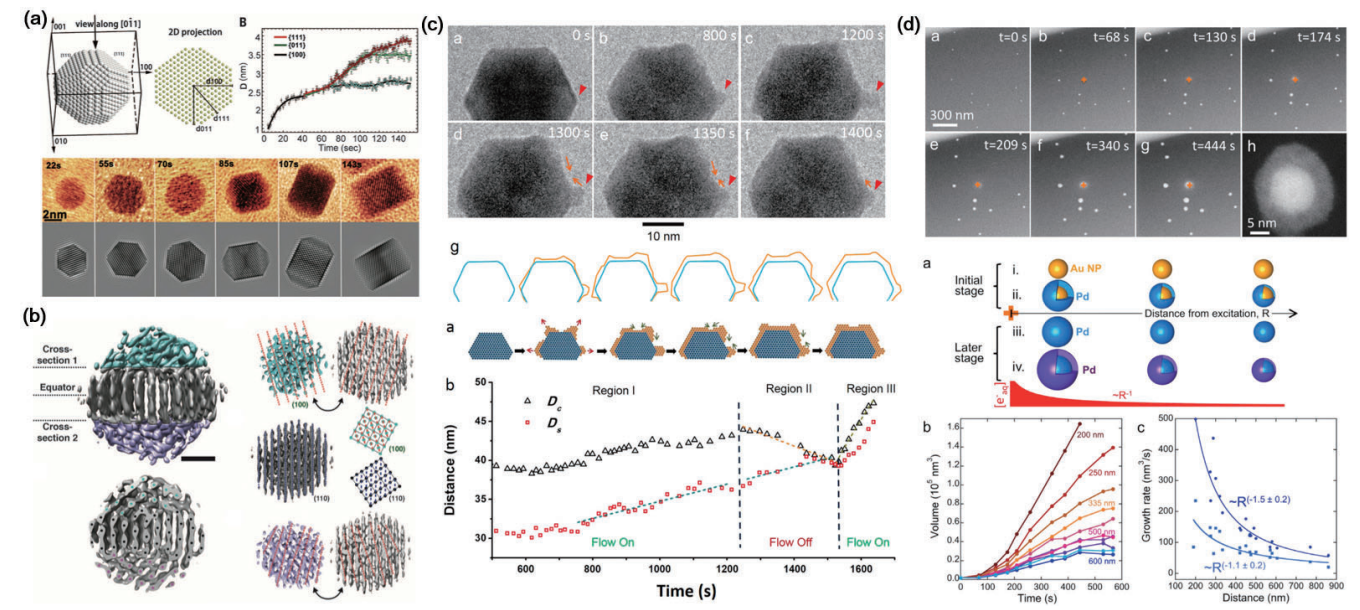

그림6. (a) Facet development during platinum nanoparticle growth" (b) 3D structure of platinum nanoparticles obtained within graphene liquid cell12 (c) Growth of gold shell on platinum nanoparticles ${ }^{13}$ (d) Growth of palladium shell on gold nanoparticle ${ }^{14}$

도 진행이 되었다. 원래 tomography를 수행하려면 수십 개의 각도로 시편을 기울여서 이미지를 얻은 다음, 이를 종합하여 3 차원 구조를 계산해서 얻어야 한다. 하지만 액 체 내에서 입자가 혼자서 회전하는 것을 이용하여 회전하 고 있는 나노입자의 이미지를 연속적으로 수천장 얻어서 계산을 통해 3 차원 구조를 도출한 연구 결과가 발표되었 다. ${ }^{2}$ 그 외에도 단일 원소 나노입자에서 벗어나, coreshell 구조를 가진 나노입자의 형성 과정에 대한 연구도 진행되었다. 먼저 core가 될 seed 나노입자를 미리 만들
어서 액상 용기에 넣은 다음, shell이 될 원소가 들어있는 전구체 용액을 흘려주며 투과전자현미경 내에서 전자빔 을 조사하여 seed 나노입자 위에 shell이 형성되는 것을 관측한 결과들이 발표되었다. ${ }^{13,14}$ (그림6)

나노입자 합성에서는 나노입자들끼리 들러붙지 않고 분산된 상태로 존재할 수 있게 해주는 계면활성제가 중요 한데, 이 계면활성제의 농도에 따라 입자의 형태가 어떻 게 바뀌는지에 대한 연구도 진행이 되었다. 계면활성제 농도가 낮을 때는 상대적으로 coalescence가 쉽게 일어
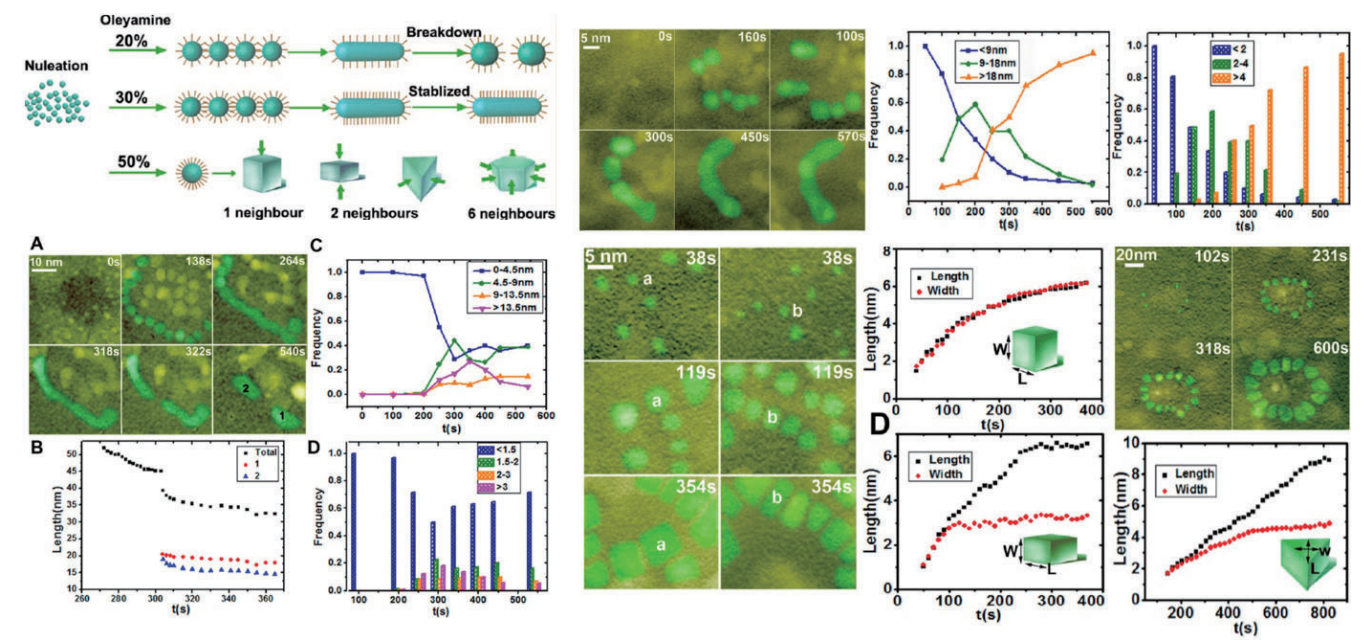

그림7. Shape evolution of platinum iron nanoparticles depending on concentration of oleylamine in precursor solution ${ }^{15}$ 


\section{특 집 묘 홍재영, 천동원}
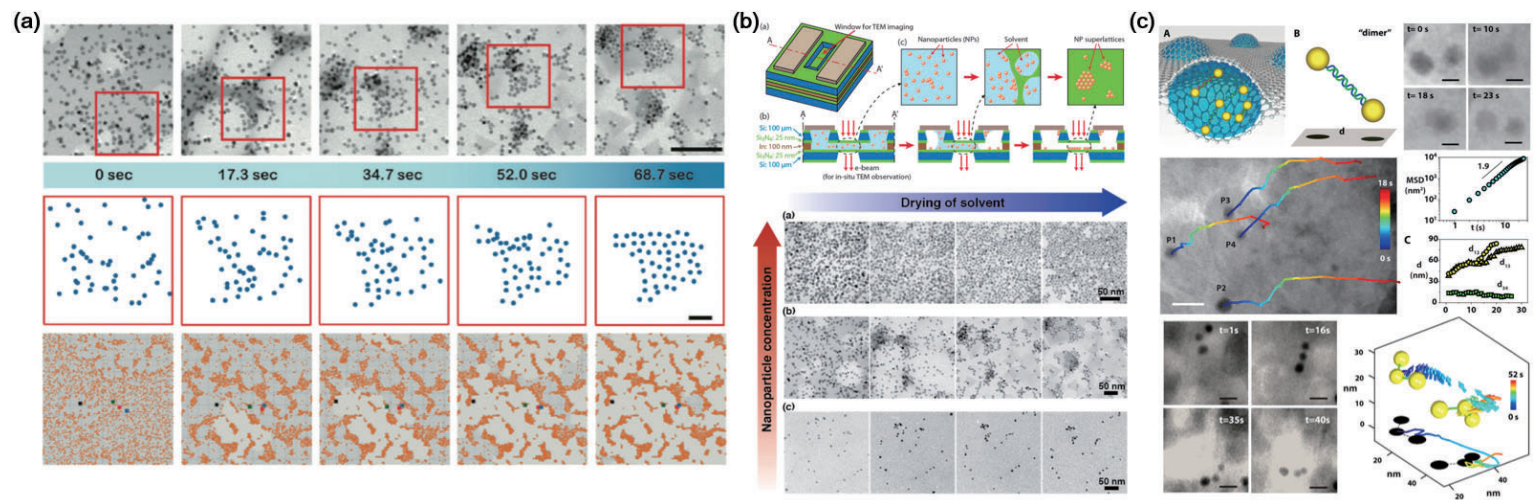

그림 8. (a) Observation of nanoparticle superlattice formation during ${ }^{16}$ (b) Observation of nanoparticle superlattice formation during solvent evaporation $^{17}$ (c) 3D motion of DNA conjugated gold nanoparticles in graphene liquid cell18

나 처음에 구형 형태로 생성된 나노입자들이 합쳐져서 $\operatorname{rod}$ 형태를 띄게 되는 경우들이 있지만, 계면활성제가 너 무 부족할 경우에는 합쳐져서 만들어진 nanorod의 표면 을 계면활성제가 충분히 덮지 못하여 다시 작은 크기의 나노입자로 나눠지는 현상이 발견되었다. 또 계면활성제 농도가 높은 경우에는 입자간 coalescence는 억제되고 주변에 있는 다른 나노입자들에 의해 나노입자의 형태가 결정된다는 결과도 발표되었다. ${ }^{15}$ (그림 7)

나노입자의 성장 과정 뿐만 아니라 나노입자의 액체 내 움직임에 대한 연구도 진행이 되었다. 나노입자들은 액체 내에서 자유롭게 움직이기에 brownian motion을 하게 되지만, 전자빔에 의해 액체가 움직이게 되면 액체의 움 직임을 따라 나노입자가 움직이는 것이 관측되었다. 특히
액체가 마르면서 액체와 기체의 경계면에 나노입자들이 모이면서 액체가 모두 말라버리는 종국에는 나노입자들 이 초격자 배열을 이루는 것을 보였다. 16,17 그리고 서로 다 른 두 나노입자를 유기물로 연결시켜서 연결된 나노입자 들이 회전하고 움직이는 현상을 관찰한 연구 결과도 발표 되었다. ${ }^{18}$ (그림 8)

\section{2-3. 나노소재 변화 실시간 관찰연구}

사람들은 나노입자 형성과정외에 입자가 녹는 현상이 나 galvanic replacement와 같이 입자의 형태가 변하는 현상들에 대한 연구에도 관심을 기울였다. 전자빔의 조사 량에 따라 액체 내부에 산화 분위기가 강해져서 금속 나 노입자가 녹는 경우도 있지만, 의도적으로 입자를 녹일

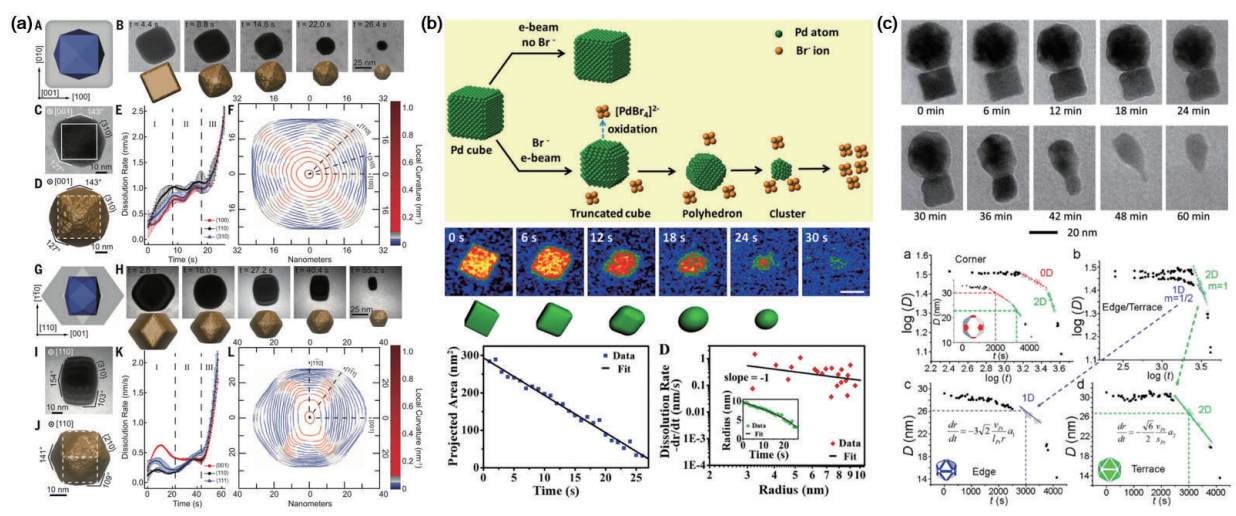

그림 9. (a) Etching behavior of gold nanoparticles in graphene liquid celli9 (b) Dissolution of palladium nanocube caused by presence of bromine ion ${ }^{20}$ (c) Oxidative ethcing behavior of platinum nanoparticles ${ }^{21}$ 
수 있는 물질을 넣어서 etching 과정을 연구한 결과들이 있다. 금속들은 할로겐 족 원소와 반응하여 쉽게 화합물 을 형성한다. 이 특성을 이용하여 미리 만들어놓은 금속 입자가 분산되어 있는 용액에 $\mathrm{Cl}$ 이온이나 $\mathrm{Br}$ 이온을 주 입하여 전자빔이 조사될 때 입자의 etching이 일어나게 한 뒤, 그 녹는 과정을 관찰한 연구가 진행되었다. 입자 의 꼭짓점과 모서리 부분에서부터 etching이 시작되어 전체적으로 둥근 형태를 띄다가 결국에는 모두 녹아버리 는 모습을 보였다. ${ }^{19-21}$ (그림 9)

서로 다른 원소간의 환원전위 차이로 인해 일어나는 galvanic replacement 현상도 액상 투과전자현미경을 통해 연구되었다. 은 나노입자를 금 전구체 용액이나 팔 라듐 전구체 용액에 넣어서 관찰한 결과, 나노입자를 구 성하던 은은 이온화되어 용액으로 녹아 나오고, 용액에 있던 금이나 팔라듐 이온이 환원되어 은 나노입자 위에 쌓이는 것이 관측되었다. ${ }^{22,23}$ 특히 정육면체 은 나노입자 를 금 전구체 용액에 담갔을 때, 상대적으로 표면에너지 가 높은 꼭짓점과 모서리 부분에 금 원자들이 쌓이고, 대 신 면 부분의 은들이 이온화되어 녹아 나오는 것이 확인 되었다. 구형의 은 나노입자를 팔라듐 전구체 용액에 담 갔을 때는 시간이 지나면서 은은 전부 이온화되어 녹아버 리고, 팔라듐이 원래 은 나노입자였던 것의 표면에 쌓이 면서 종국에는 속이 비어있는 팔라듐 hollow 나노입자가
형성되는 것이 관찰되었다. (그림 10)

이 외에도 전지에서 일어나는 전해질과 전극 사이의 반 응을 연구하기 위해 많은 연구들이 진행되고 있다. 앞서 말했던 나노입자 성장 과정 실시간 관찰 연구와는 달리, 전지 반응 연구를 위한 실험에서는 투과전자현미경의 전 자가 전해질과 반응하지 않도록 전자빔 조사량이 임계점 이하로 낮게 유지되어야 하기에 더 세심한 주의가 필요하 다. 리튬 이온 전지에서 일어나는 반응을 연구가 계속 시 도되어지고 있다. 그래핀셀 내에서 리튬 전해질 용액 안 에 있는 실리콘 나노입자에 전자빔을 조사하여 lithiation 거동을 보고한 연구결과가 있었다. 초기 lithiation 반응 에서는 실리콘의 팽창이 비등방성을 띄다가 초기단계를 지난 후에는 팽창이 모든 방향으로 동일하게 일어나는 현 상을 밝혀내었다. ${ }^{24}$ 리튬 이온 전지의 음극에서 일어나는 열화 반응을 분석하기 위해 비정질 실리콘, 결정성 알루 미늄, 결정성 금 세가지 박막 전극을 모델로 사용하여 lithiation, delithiation 거동을 관찰한 연구도 진행이 되었다. 결정성 물질과 비정질 물질의 lithiation 거동이 다른 것을 확인하였고, 리튬이 금속안에 들어가는 영역이 어떤 식으로 확장되는지 분석하였다. ${ }^{25}$ 전지 반응 효율에 큰 영향을 끼치는 solid electrolyte interphase (SEI)의 형성을 그래핀셀을 사용하여 실시간으로 관찰하는 연구 도 진행되었다. 전자빔이 조사되는 상황에서 전해질 내의 (a)

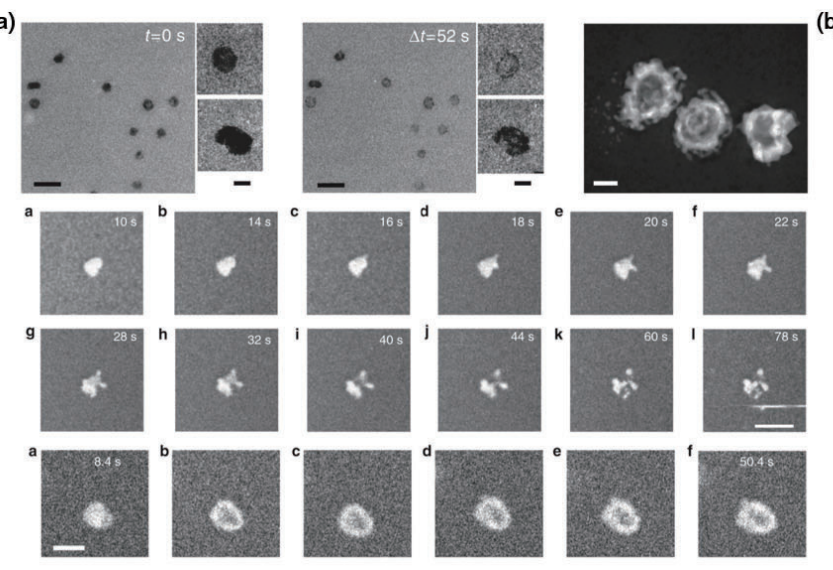

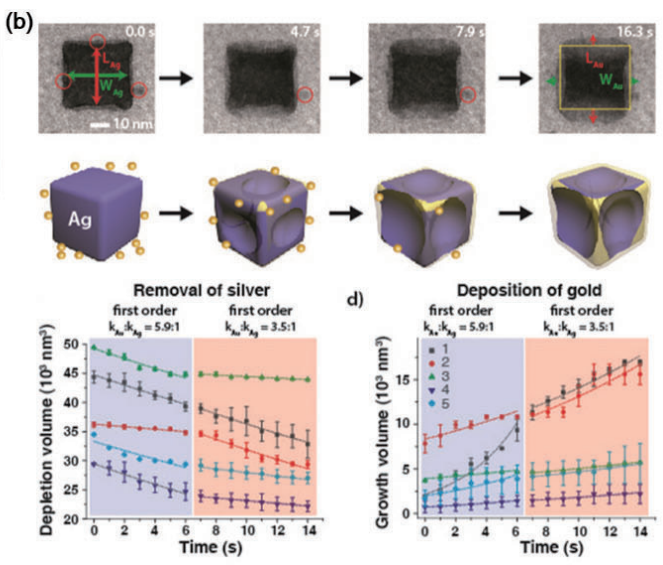

그림 10. (a) Silver-palladium galvanic replacement reaction on silver nanoparticles ${ }^{22}$ (b) Silver-gold galvanic replacement reaction on silver nanoparticles and deposition of gold on particles $^{23}$ 
5. Y. Wang, S. Wang, and X. Lu, "In Situ Observation of the Growth of ZnO Nanostructures Using Liquid Cell Electron Microscopy" J. Phys. Chem. C122 (2018)

6. T. J. Woehl, J. E. Evans, l. Arslan, W. D. Ristenpart, and N. D. Browning, "Direct in Situ Determination of the Mechanisms Controlling Nanoparticle Nucleation and Growth" ACS Nano 6, 10 (2012)

7. D. Alloyeau, W. Dachraoui, Y. Javed, H. Belkahla, G. Wang, H. Lecoq, S. Ammar, O. Ersen, A. Wisnet, F. Gazeau, and C. Ricolleau, "Unravelling Kinetic and Thermodynamic Effects on the Growth of Gold Nanoplates by Liquid Transmission Electron Microscopy" Nano Lett. 15 (2015)

8. S. G. Kwon and T. Hyeon, "Formation Mechanisms of Uniform Nanocrystals via Hot-Injection and Heat-Up Methods" Small 7, 19 (2011)

9. H. Zheng, R. K. Smith, Y.-w. Jun, C. Kisielowski, U. Dahmen and A. P. Alivisatos, "Observation of Single Colloidal Platinum Nanocrystal Growth Trajectories" Science 324 (2009)

10. H.-G. Liao, L. Cui, S. Whitelam, H. Zheng, "RealTime Imaging of Pt3 Fe Nanorod Growth in Solution" Science 336 (2012)

11. H.-G. Liao, D. Zherebetskyy, H. Xin, C. Czarnik, P. Ercius, H. Elmlund, M. Pan, L.-W. Wang and H. Zheng, "Facet Development during Platinum Nanocube Growth" Science 345 (2014)

12. J. Park, H. Elmlund, P. Ercius, J. M. Yuk, D. T. Limmer, Q. Chen, K. Kim, S. H. Han, D. A. Weitz, A. Zettl and A. P. Alivisatos, "3D structure of Individual Nanocrystals in Solution by Electron Microscopy" Science 349 (2015)

13. J. Wu, W. Gao, J. Wen, D. J. Miller, P. Lu, J.-M. Zuo, and H. Yang, "Growth of Au on Pt Icosahedral Nanoparticles Revealed by Low-Dose In Situ TEM" Nano Lett. 15 (2015)

14. E. A. Sutter and P. W. Sutter, "Determination of Redox Reaction Rates and Orders by In Situ Liquid Cell Electron Microscopy of Pd and Au Solution Growth" J. Am. Chem. Soc. 136 (2014)

15. H. - G. Liao and H. Zheng, "Liquid Cell Transmission Electron Microscopy Study of Platinum Iron Nanocrystal Growth and Shape Evolution" J. Am. Chem. Soc. 135 (2013)

16. J. Park, H. Zheng, W. C. Lee, P. L. Geissler, E. Rabani, and A. P. Alivisatos, "Direct Observation of Nanoparticle Superlattice Formation by Using Liquid
Cell Transmission Electron Microscopy" ACS Nano 6, 3 (2012)

17. W. C. Lee, B. H. Kim, S. Choi, S. Takeuchi, and J. Park, "Liquid Cell Electron Microscopy of Nanoparticle Self-Assembly Driven by Solvent Drying" J. Phys. Chem. Lett. 8 (2017)

18. Q. Chen, J. M. Smith, J. Park, K. Kim, D. Ho, H. I. Rasool, A. Zettl, and A. P. Alivisatos, "3D Motion of DNA-Au Nanoconjugates in Graphene Liquid Cell Electron Microscopy" Nano Lett. 13 (2013)

19. X. Ye, M. R. Jones, L. B. Frechette, Q. Chen, A. S. Powers, P. Ercius, G. Dunn, G. M. Rotskoff, S. C. Nguyen, V. P. Adiga, A. Zettl, E. Rabani, P. L. Geissler and A. P. Alivisatos, "Single-Particle Mapping of Nonequilibrium Nanocrystal Transformations" Science 354 (2016)

20. Y. Jiang, G. Zhu, F. Lin, H. Zhang, C. Jin, J. Yuan, D. Yang, and Z. Zhang, "In situ Study of Oxidative Etching of Palladium Nanocrystals by Liquid Cell Electron Microscopy" Nano Lett. 14 (2014)

21. J. Wu, W. Gao, H. Yang, and J.-M. Zuo, "Dissolution Kinetics of Oxidative Etching of Cubic and Icosahedral Platinum Nanoparticles Revealed by in Situ Liquid Transmission Electron Microscopy" ACS Nano 11 (2017)

22. E. Sutter, K. Jungjohann, S. Bliznakov, A. Courty, E. Maisonhaute, S. Tenney \& P. Sutter, "In Situ LiquidCell Electron Microscopy of Silver - Palladium Galvanic Replacement Reactions on Silver Nanoparticles" Nat. Comm. 5 (2014)

23. S. F. Tan, G. Lin, M. Bosman, U. Mirsaidov, and C. A. Nijhuis. "Real-Time Dynamics of Galvanic Replacement Reactions of Silver Nanocubes and $\mathrm{Au}$ Studied by Liquid-Cell Transmission Electron Microscopy" ACS Nano 10 (2016)

24. J. M. Yuk, H. K. Seo, J. W. Choi, and J. Y. Lee, "Anisotropic Lithiation Onset in Silicon Nanoparticle Anode Revealed by in Situ Graphene Liquid Cell Electron Microscopy" ACS Nano 8, 7 (2014)

25. A. J. Leenheer, K. L. Jungjohann, K. R. Zavadil, and C. T. Harris, "Phase Boundary Propagation in Li-Alloying Battery Electrodes Revealed by LiquidCell Transmission Electron Microscopy" ACS Nano 10 (2016)

26. J. Y. Cheong, J. H. Chang, H. K. Seo, J. M. Yuk, J. W. Shin, J. Y. Lee, I.-D. Kim, "Growth Dynamics of Solid Electrolyte Interphase Layer on $\mathrm{SnO}_{2}$ Nanotubes 


\section{특 집 ㅁㅁ 홍재영, 천동원}

Realized by Graphene Liquid Cell Electron Microscopy" Nano Energy 25 (2016)

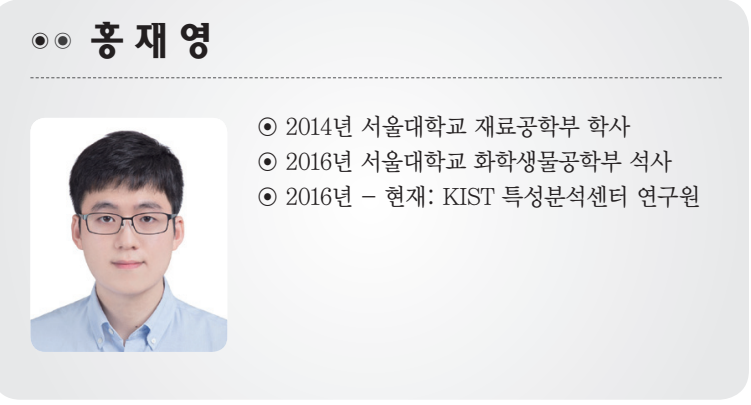

\section{○○ 천 동 원}

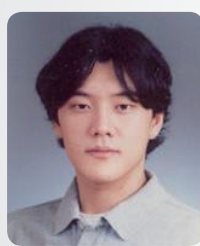

• 2005년 연세대학교 재료공학과 학사

๑ 2007년 연세대학교 재료공학과 석사

๑ 2012년 KIST 생체재료연구단 연구원

• 2016년 UCSD 재료공학과 박사

๑ 2016년 - 현재: KIST 특성분석센터 선임연구원 